\title{
Influence of Temperature Changes in Lower Atmosphere on Dynamics of Glaciers and Height of Snow Line on Elbrus
}

\author{
Kalov R.Kh. \\ Federal State Budgetary Institution \\ High-mountain Geophysical Institute \\ Nalchik, Russia \\ ruslan_kalov@mail.ru
}

Kesheva L.A.

Department of cloud physics

Federal State Budgetary Institution

High-mountain Geophysical Institute

Nalchik, Russia

kesheva.lara@yandex.ru

Tashilova A.A.

Department of cloud physics

Federal State Budgetary Institution

High-mountain Geophysical Institute

Nalchik, Russia

tashilovaa@mail.ru

\author{
Bekkiyev M.Yu. \\ Federal State Budgetary Institution \\ High-mountain Geophysical Institute \\ Nalchik, Russia \\ mbekk@mail.ru \\ Kalov Kh.M. \\ Chief researcher \\ Federal State Budgetary Institution \\ High-mountain Geophysical Institute \\ Nalchik, Russia \\ kalov1942@mail.ru \\ Shugunov L.Zh. \\ Nalchik, Russia \\ lion.shugunov@mail.ru
}

\author{
Shugunov T.L. \\ Department of informatics and information security \\ Institute of informatics, electronics and robotics \\ Kabardino-Balkarian state university \\ Nalchik, Russia \\ tshugunov@yandex.ru
}

\begin{abstract}
The results of monitoring of the surface atmosphere temperature in the Elbrus region for the period of 1961-2017, including the period of intensive climate warming (1976-2017), are presented. It has been established that in summer seasons average temperatures have increased significantly. The growth rate for the period of 1961-2017 is $0.31{ }^{\circ} \mathrm{C} / 10$ years, increasing to $0.43{ }^{\circ} \mathrm{C} / 10$ years in the period of intense warming. The effect of warming on the height of snow cover, degradation of glaciation and height of the snow line on Elbrus are shown. The process of glaciation degradation is heterogeneous in time and space. Glaciers located in the southeast, retreat more intensely than the western and northwestern. The height of the snow line in the summer of $\mathbf{2 0 1 5}$ rose to the level of $\mathbf{4 7 0 0}$ meters above sea level (a.s.l.) for the first time.
\end{abstract}

Keywords-temperature changes, the dynamics of the Elbrus glaciers, the height of the snow line

\section{INTRODUCTION}

Due to the intensive development of the Elbrus region as an international recreation center in the mountains and the need to ensure the safety of tourists, the local population, protection of recreational facilities, infrastructure and environmental conservation, an actual problem is to continuously monitor natural hazards and processes (glacier degradation, glacial lakes, mudflows, avalanches, etc.), meteorological parameters (temperature, precipitation, snow cover). On the territory of the all-season tourist, the recreational complex (ATRC) "Elbrus" provides for a comprehensive prospective development of the resort, which includes not only the creation of ski and transport infrastructure, but also the solution of issues of protecting the Elbrus region from mudflow and avalanche danger, breakthroughs of glacial lakes and other climatic risks.

These risks are associated with climatic changes in surface air temperature, the dynamics of glacier degradation, 
an increase in the ablation zone, contributing to the acceleration of the rate of reduction of the glacier area, etc.

The purpose and objectives of this work is a qualitative assessment of the intensive influence of climate warming on the melting of glaciers, snow cover parameters and the height of the snow line on Elbrus. Studies of changes in air temperature were carried out over the full measurement period from 1961 to 2017 and for the period from 1976 to 2017, since 1976 was estimated by members of the Intergovernmental Panel on Climate Change (IPCC) as the beginning of intense global warming.

The paper presents the results of research:

- the change in the surface air temperature regime in the Elbrus region within 1961-2017 and the modern period of intense global warming since 1976;

- parameters of snow cover and height of the snow line on Elbrus;

- dynamics of glacier degradation.

\section{METHODS AND MATERIALS}

Data from the high-mountain meteorological station Terskol, satellite images from the Russian and foreign spacecraft, aerial photographs and ground photographs are the source materials.

For the analysis of the source material, we used:

- decryption of satellite images and aerial photographs, a comparative analysis of the results of interpretation with photographs obtained during route surveys;

- construction of average values of meteorological parameters, anomalies and trends for calendar seasons and the whole year. The estimation of linear trend coefficients is obtained by the least squares method. The average values of meteorological parameters, standard deviations, norms and anomalies of average temperatures and precipitation for the period 1961-2017 are obtained.

\section{RESULTS}

\subsection{Climate changes and their manifestations in the vicinity of the Mt. Elbrus (KBR)}

According to the experts of the United Nations, damage caused to world economy by negative consequences of climate changes and adverse conditions of weather makes $70 \%$ of damage, which is registered after impact of natural disasters in general. In Russia where hydro-meteorological and climatic conditions are subject to big fluctuations, the damage from the dangerous hydro-meteorological phenomena $(\mathrm{DPh})$ is $80-90 \%$ [1]. Influence of climate change on economy and society is shown, first of all, due to growth of quantity of DPh. The tendency of growth in the number of DPh (avalanches, mudflows, breaks of glacial lakes, etc.) is noted also in the North Caucasus, in particular, in the vicinity of the Mt. Elbrus (KBR) [2], which is explained, and there are also changes in temperature condition of the region [3-4].

The World Meteorological Organization (WMO) stated that globally over the past 30 years, the number of dangerous hydro-meteorological phenomena has doubled.

\subsubsection{Change in surface air temperature in the vicinity of the Mt. Elbrus for the periods of 1961-2017 and 1976- 2017.}

The studies were performed for series of temperature values according to the weather station Terskol for the period of 1961-2017 and the period of global warming of 1976-2017. Height of the snow cover (SC) was investigated during 1980-2017.

\subsubsection{Temperature condition}

Data annual and seasonal temperatures (average, maximum and minimum) and also data on change of temperature condition on the meteorological station Terskol are provided in Table 1. On Terskol's meteorological station during 1961-2017 average annual temperature remained almost constant, during global warming of 1976-2017 small increase in growth rate of temperature from $0.05{ }^{\circ} \mathrm{C} / 10$ years to $0.14{ }^{\circ} \mathrm{C} / 10$ years took place (Table 1 ). During 2006-2017 the maximum temperatures have increased, and minimum temperatures have decreased (Table 1).

During winter seasons of 1961-2017 at the Terskol station reduction of average winter temperature by "- 0.11 ${ }^{\circ} \mathrm{C} / 10$ years" was observed, since 1976 the rate of change of average winter temperatures has decreased to "-0.03 ${ }^{\circ} \mathrm{C} / 10$ years". During spring seasons of 1961-2017 increase in average temperature by $0.02{ }^{\circ} \mathrm{C} / 10$ years", and since 1976 on "0.09 ${ }^{\circ} \mathrm{C} / 10$ years" were observed. During autumn seasons of 1961-2017 reduction of temperature by "-0.02 ${ }^{\circ} \mathrm{C} / 10$ years", and since 1976 by $" 0.042{ }^{\circ} \mathrm{C} / 10$ years" were observed. Unlike spring and autumn seasons, during summer seasons average temperatures tended significant growth. Growth rate of summer temperatures during 19612017 was $0.31{ }^{\circ} \mathrm{C} / 10$ years (Fig. 1), increasing up to 0.43 ${ }^{\circ} \mathrm{C} / 10$ years during 1976-2016. A trend statistically significant at $95 \%$ the level of a confidential interval, a trend contribution to dispersion is $\mathrm{D}=33 \%$. 
TABLE 1. TEMPERATURE CONDITION AND ANOMALIES FOR 1961-2017, TERSKOL

\begin{tabular}{|l|c|c|c|c|c|}
\hline \multicolumn{1}{|c|}{ Temperature, ${ }^{\circ} \mathbf{C}$} & year & winter & spring & summer & autumn \\
\hline Average temperature (1961-2017) & 2.6 & -6.6 & 1.8 & 11.4 & 3.7 \\
\hline Standard deviation & 0.64 & 1.53 & 0.88 & 0.89 & 1.03 \\
\hline Norm (1961-1990, basic period) & 2.5 & -6.4 & 1.8 & 11.0 & 3.8 \\
\hline Average anomaly (1961-2017) & 0.0 & $-0,2$ & 0.0 & 0.4 & -0.1 \\
\hline The slope of a trend $(1961-2017),{ }^{\circ} \mathrm{C} / 10$ years & 0.05 & $-0,11$ & 0.02 & $\mathbf{0 . 3 1}$ & -0.02 \\
\hline The slope of a trend (1976-2017), ${ }^{\circ} \mathrm{C} / 10$ years & $\mathbf{0 . 1 4}$ & $-0,03$ & 0.09 & $\mathbf{0 . 4 3}$ & 0.042 \\
\hline $\begin{array}{l}\text { Average of absolute maxima of temperatures (2006- } \\
\text { 2017) }\end{array}$ & 23.6 & 4,1 & 15.7 & 23.6 & 18.5 \\
\hline The slope of a trend (2006-2017), ${ }^{\circ} \mathrm{C} / 1$ year & 0,63 & 1,1 & 0.55 & 0.63 & 0.66 \\
\hline Average of absolute minima of temperatures (2006-2017) & -16.6 & -16.4 & -10.7 & 3.6 & -9.1 \\
\hline The slope of a trend $(2006-2017),{ }^{\circ} \mathrm{C} / 1$ year & -1.05 & -1.03 & -1.04 & -0.53 & -0.97 \\
\hline
\end{tabular}

* the greatest deposits of components of variables for a change in average annual temperature are in bold;

** negative tendencies of change in the variable are highlighted with gray.

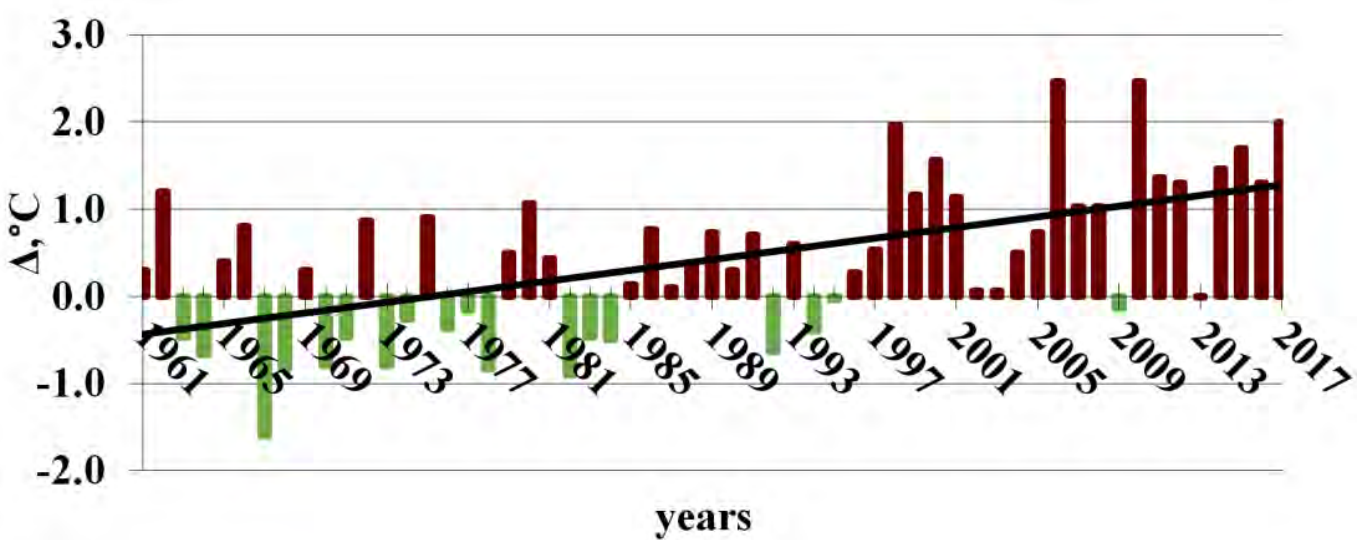

Fig. 1. Summer anomalies of temperature (deviation from the norm 1961-1990) with trend during 1961-2017.

\subsubsection{Snow cover in vicinity of the Mt. Elbrus}

Observations of snow cover begin during the autumn period from the moment of appearance of the first (temporary) snow cover and continue before its total disappearance during the spring period. According to works $[3,4]$ for the last 50-60 years, in the south of the European territory of Russia (except for a mountain part), increase in average decade height of snow cover by $0.35 \mathrm{~cm} / 10$ years with the maximum growth rate of height of snow cover in a foothill zone was observed. Since 1976 there was a considerable shift of the beginning of appearance of snow cover towards later dates $(+3$ days $/ 10$ years) and the small shift of the end of a descent of snow cover to late dates for 0.7 days/years. Appearance/destruction of steady snow cover also displaced towards later dates by 0.6 days/ 10 years and 1.4 days/10 years, respectively.

Thus, at the high-mountain meteorological station Terskol, from 1961 to 2017 significant warming was observed in the summer; during other seasons and throughout the whole year significant trends of temperatures were absent here. During global warming, since 1976, average annual temperature in Terskol increased by 0.14 ${ }^{\circ} \mathrm{C} / 10$ years due to significant increase in summer temperatures by $0.43^{\circ} \mathrm{C} / 10$ years.

The winter sums of precipitations decreased during 1961-2017 (-0.53 mm/10 years) and during the modern period $(-4.86 \mathrm{~mm} / 10$ years $)$. Therefore, the average monthly height of snow cover during the winter period statistically significantly decreased by $7.2 \mathrm{~cm} / 10$ years in the last forty years.

\subsection{Dynamics of glaciers degradation of Elbrus}

The largest peak of Europe, Mount Elbrus is well studied like no other in Russia [5-8]. The area of Elbrus glaciers of 2015 is estimated by us at 115.4 sq. km, and minus the total areas of rocky ledges and moraines on glaciers $(6.6$ sq. $\mathrm{km})-$ 108.8 sq.km. The general decrease of the area of glaciers from 1957 for 2015 made 14\%. In Fig. 2 it is shown that glaciers receded in $1957-2015$.

The process of the glaciers degradation of Elbrus is heterogeneous in time and space. 


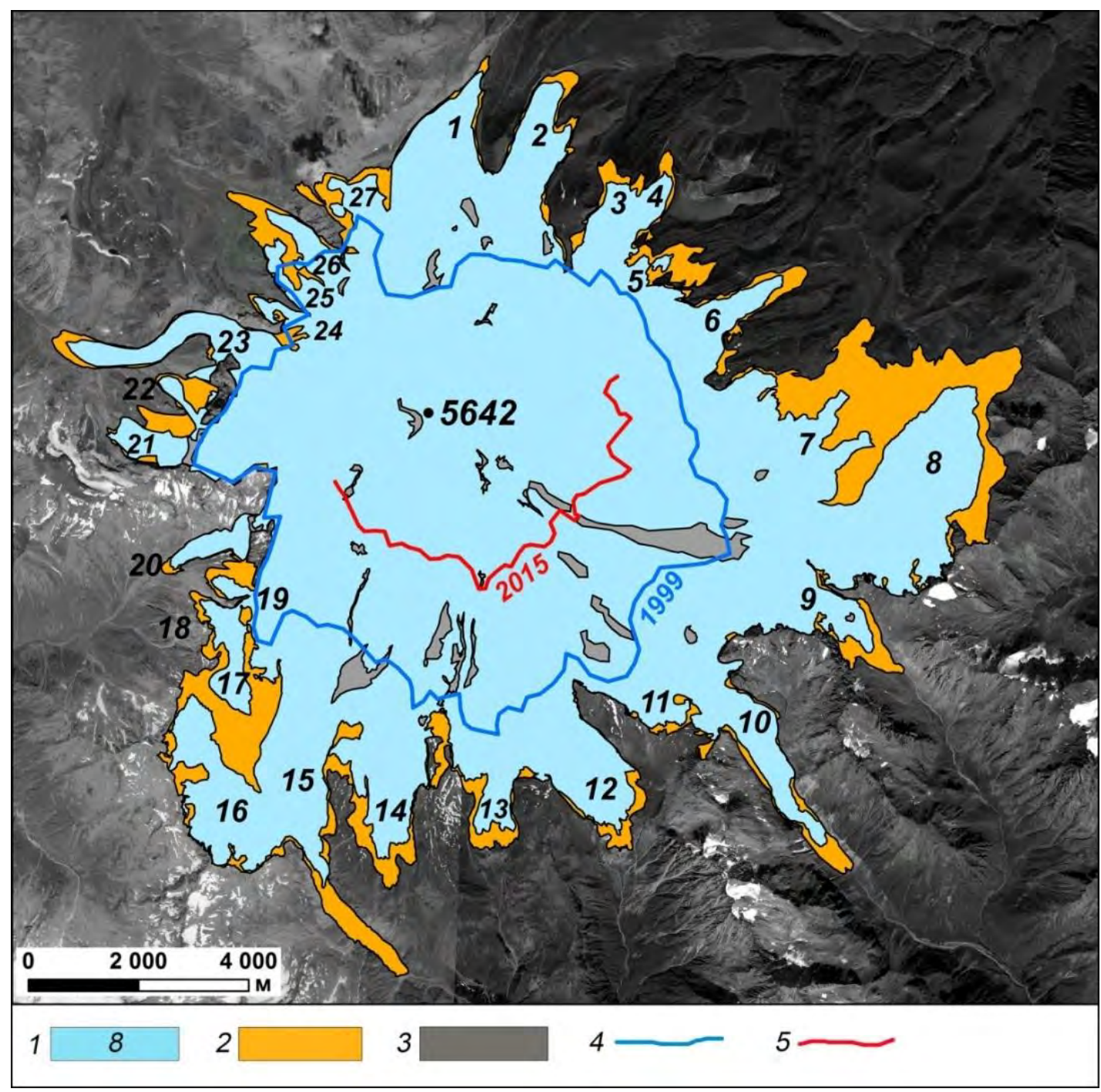

Fig. 2. Changes of Elbrus glaciers for 1957-2015:

1 - contours of glaciers in 2014-2015 and their numbers, 2- melted areas of glaciers for 1957-2015, 3 - ice free areas inside glacier contours, 4 - snow line of 09.08.1999, 5 - the snow line of 23.08.2015.

Numbers of glaciers: 1 - Ulluchiran, 2 - Karachaul, 3 - Ullukol, 4 - Ullumaliyenderku, 5 - No. 4 [9], 6 - Mikelchiran, 7 - Birdzhalychiran, 8 - Chungurchatchiran, 9 - Irikchat, 10 - Irik, 11 - No. 25 [9], 12 - Terskol, 13 - Garabashi, 14 - Maly Azau, 15 - Bolshoy Azau, 16 - Azau Zapadny, 17 - Hotyu-Tau, 18 - No. 311 [10], 19 No. 312 [10], 20 - Ullukam, 21 - No. 316 [10], 22 - No. 317 [10], 23 - Kyukyurtlyu, 24 - No. 319 [10], 25 - Bityuktyube (left), 26 - Bityuktyube (right), 27 Ulluchiran (western).

The types of monitoring were aerospace - the use of multi-time aerospace information (1957-2016); aero visual surveys (2009-2016 and helicopter overflights in the second half of the 20th century); route and expedition ground surveys $(2007,2009,2010,2015,2016)$. As a result of this monitoring, the search and analysis of data on Internet resources (ground and helicopter photographs) and analysis of literature data has been established: in the 21 st century, the rate of degradation of the Elbrus glaciers more than doubled.

The area of glaciers in different years from 1957 to 2015 decreased: in 1957 the area was 134.2 sq.km; in 1997 124.9 sq.km; in 2015 - 115.4 sq.km (the area of glaciers in
2015 was 108.8 sq.km without rocky ledges and moraines). The average decrease of the area of Elbrus glaciers was in $1957-1997-0.23$ sq.km/year; in $1998-2015-0.53$ sq.km/year.

During 40 years, from 1957 to 1997 , the area of glaciers decreased by 9.3 sq.km, and in 18 years from 1998 to 2015 - by 9.5 sq.km. In this way for the last 18 years, the area of Elbrus glaciers decreased on average more than twice quicker in comparison with the previous 40 years (19571997).

According to $[2,4]$, the sharp retreat of glaciers since the late 90 s of the 20 th century was due to a significant increase in summer temperatures by $0.43{ }^{\circ} \mathrm{C} / 10$ years $[3,4]$. An 
increase in the rate of retreat of glaciers is most clearly demonstrated by the Maly Azau and Terskol glaciers [2, 4]. In the period of 2007-2012, the area of the Garabashi glacier reduced approximately by 25 thousand sq.m per year (length decreased at a speed of $26 \mathrm{~m} /$ year), the Terskol glacier - up to 35 thousand sq.m per year (length decreased by 20 $\mathrm{m} /$ year). Speed of reliction of glaciers those years was 3time higher than in the 20th century. The general decrease of the area of the Maly Azau glacier in 1957-2015 made 1.2 sq.km.

Other ratio of rates of reliction in the 20th and 21st centuries was recorded for the Bolshoy Azau glacier (No. 15, No. 16 and No. 17 in Fig. 2). From 1957 to 1978 the Bolshoy Azau glacier receded almost by $1300 \mathrm{~m}(62$ $\mathrm{m} /$ year), and from 2007 to 2015 - by $330 \mathrm{~m}$ (41 m/year). The area of tongue of the Bolshoy Azau glacier decreased in $1957-1997$ by 0.57 sq.km (73.5\%), and in $1997-2015$ - by 0.2 sq. $\mathrm{km}(26.5 \%)$. As a result the glacier broken into three independent glaciers.

It would seem that in recent years the glacier has almost ceased to shrink, but if we add to the area of the glacier tongue reduction the area of the reduced supply area, then we get another ratio $-49.7 \%$ to $50.3 \%$. The general reduction of the area of the Bolshoy Azau glacier in 1957-2015 has made -3.2 sq. $\mathrm{km}$.

The area of the Dzhikugankanez glacier (Fig. 3), which broke into the Chungurchatciran and Birjalychiran glaciers, for 1957-2015 decreased by $6.03 \mathrm{~km}^{2}$, of which 1957-1997 accounted for $2.63 \mathrm{~km}^{2}(43.6 \%)$, and $1997-2015-3.40 \mathrm{~km}^{2}$ $(56.4 \%)$ [2]. Chungurchat Glacier length decreased in $1957-$ 1997 by $645 \mathrm{~m}$, in $1997-2015$ - by $420 \mathrm{~m}$. The Birdzhalychiran glacier receded quicker. In 1957-1997 its length decreased by $1440 \mathrm{~m}$, and in 1997-2015 - by $560 \mathrm{~m}$.

Along with the glaciers that considerably reduced in the 20th and 21st centuries there are glaciers which changed little during this time - the Ullukam glacier decreased by only 53.5 thousands sq.m, Kyukyurtlya - by 215 thousands sq.m.

The Kyukyurtlu glacier advanced many times, and it was even rated among the pulsating glaciers. In addition to the well-known fact of the offensive in the 80s [2], as a result of the analysis of multi-temporal space images, it was revealed that in the period of 1997-1999 under the pressure of the glacier, the array of dead ice that formed in the 80s slightly shifted. Further, this shift considerably degraded as a result of thawing. And over the 2014-2015, through this thawed patch, the narrow front of the glacier moved ahead by $20-25$ $\mathrm{m}$.

The revealed existence of the front of the ice wave in glacier tongue of the Kyukyurtlyu glacier at a distance of $400 \mathrm{~m}$ from the end of the tongue moving ahead with a speed of $30 \mathrm{~m} /$ year suggests that it is possible to continue the advance of the glacier in the future.

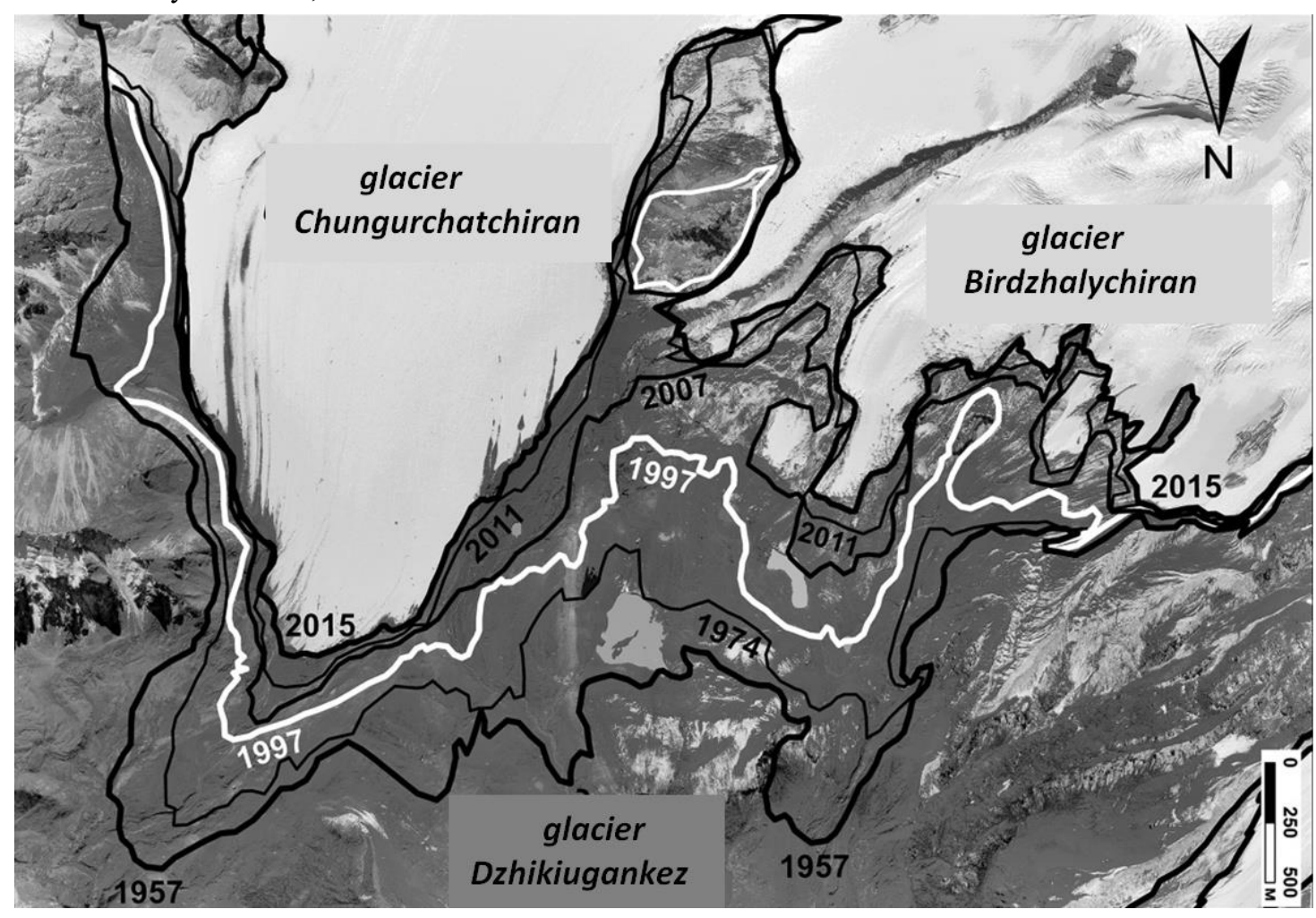

Fig. 3. Reduction of the Dzhikiugankez glacier (Chungurchatchiran and Birdzhalychiran) 
Analysis of the state of the Elbrus glaciation in different years revealed a sharp change in the position of the snow line in the summer of 2015 (see Fig. 2). At an altitude of $4700 \mathrm{~m}$ (Pastuchov's Shelter), the meltwater flows on the surface of the moraine, forming a whole network of potholes (15 holes for $115 \mathrm{~m}$ ) of width up to 1.5-2.5 m and length up to $60-80 \mathrm{~m}$. Several potholes united into one, which continued on the surface of the glacier and cut it at a distance of up to $350 \mathrm{~m}$. In all previous images, the snow line did not rise above $4000 \mathrm{~m}$, even in the anomalously hot summer of 2010. Thus, in the summer of 2015, there was a sharp increase in the area of the ablation zone, which over time can lead to a significant increase in the rate of glacier reduction.

Results of researches of dynamics of the Elbrus glaciers demonstrate that reaction of glaciers to warming of climate considerably varies from steadily stable condition of glaciers of the western sector of Elbrus before sharp reduction of glaciers of the southern and eastern sectors. It is connected with difference in morphology of glaciers, in the height of the area of food (the area of food of the Kyukyurtlyu glacier and the glaciers next to it - the western Plateau Elbrus at the height of 4900-5200 m with the ice thickness of $250 \mathrm{~m}$ ), the ends of glaciers and also conditions of loss of firm rainfall (on the western slopes, there is more rainfall).

\section{CONCLUSION}

Researches of climatic changes of surface air temperature were conducted for the basic period of measurements from 1961 to 2017, and from 1976 to 2017. By estimates of members of the Intergovernmental Panel on Climate Change (IPCC), 1976 is considered to be the beginning of intensive global warming of climate. The height of the snow cover (SC) was investigated during 1980-2017. It was established that during summer seasons, average temperatures was significantly growing. Growth rate of summer temperatures for the basic period (1961 for $2017)$ is $0.31{ }^{\circ} \mathrm{C} / 10$ years, increasing up to $0.43{ }^{\circ} \mathrm{C} / 10$ years during intensive warming from 1976 to 2017 . A trend is statistically significant at $95 \%$ level of a confidential interval; a trend contribution to dispersion is $\mathrm{D}=33 \%$.

The winter sums of precipitation decreased during the basic period from 1961 to $2017(-0.53 \mathrm{~mm} / 10$ years $)$, and during the modern period since 1976 ( $-4.86 \mathrm{~mm} / 10$ years). Therefore the average monthly height of snow cover during the winter period statistically significantly decreased by 7.2 $\mathrm{cm} / 10$ years in the last forty years.

The process of glaciation degradation of Elbrus proceeds unevenly in time and space. Glaciers located in the southeast of Elbrus, retreat more intensely than the western and northwestern ones.

The area of glaciers in different years from 1957 to 2015 decreased: in 1957 it was $134.2 \mathrm{~km} 2$; in 1997 - $124.9 \mathrm{~km} 2$; and in $2015-115.4 \mathrm{~km} 2$. The average decline in the area of the Elbrus glaciers was in different periods: in 1957-1997 $0.23 \mathrm{~km} 2 /$ year; in 1998-2015 - $0.53 \mathrm{~km} 2 /$ year. For 40 years, starting from 1957, the area of glaciers decreased by 9.3 $\mathrm{km} 2$, and for 18 years from 1998 to 2015 - by $9.5 \mathrm{~km} 2$.
Those, over the past 18 years, the area of glaciers annually on average has decreased by more than 2 times faster compared with the previous 40 years. Height of an arrangement of the snow line on Elbrus in the summer of 2015 has for the first time risen to the level of $4700 \mathrm{~m}$ a.s.1. In all previous figures the snow line didn't rise higher than $4000 \mathrm{~m}$, even in abnormally hot summer of 2010. Thus, in the summer of 2015, there was a sharp jump of increase in the zone that can lead over time to significant increase in rates of reduction of glaciers.

\section{References}

[1] A.I. Bedritsky, A.A. Korshunov, L.A. Handozhko, M.Z. Shaymardanov, "The climatic system and providing hydrometeorological health and safety of Russia", Theses of reports of the World conference on climate change, Moscow on September 29 - on October 3, 2003, pp. 88-90, 2003.

[2] Zh.K. Atakuyev, M.Yu. Bekkiyev, M.D. Dokukin, Kh.M. Kalov, R.H. Kalov, A.A. Tashilova, A.V. Hatkutov, "Influence of climatic changes on dynamics of glaciers, exogenous processes and recreational complexes of vicinity of the Mt. Elbrus", Reports of AMAH, Vol. 18. No. 1, pp. 62-80, 2016.

[3] B.A. Ashabokov, A.V. Shapovalov, A.A. Tashilova, "Analysis of Changes in the Natural and Climatic Conditions of the Functioning of the Construction Industry (Operation of Buildings and Structures) in the Region», Materials Science Forum. ISSN: 1662-9752, vol. 931, pp. 1031-1036, October, 2018 [International scientific and technical conference "Construction and architecture: theory and practice of development of branch of 2018" (CATPID 2018), p. 1340, 2018].

[4] R.Kh. Kalov, Kh.M. Kalov, L.A. Kesheva, «Environmental Aspects of Natural and Climatic Changes in the ElbrusRegion (KabardinoBalkar Republic)», Materials Science Forum. ISSN: 1662-9752, vol. 931, pp 1063-1069, October, 2018 [International scientific and technical conference "Construction and architecture: theory and practice of development of branch of 2018" (CATPID 2018), p. 1340, 2018].

[5] I.B. Seynova, E.A. Zolotaryov, Glaciers and mudflows of vicinity of the Mt. Elbrus. (Evolution of freezing and torrential activity). Moscow: Scientific world, 2001.

[6] M.D. Dokukin, E.A. Savernyuk, A.M. Bagov, A.V. Markina, "About reorganization of hydrographic network of the northeast foot of Elbrus (basins of the rivers Birdzhaly-Su and Cara-Kaya-Su)", Ice and snow, No. 2 (118), pp. 23-30, 2012.

[7] M.D. Dokukin, "Modern dynamics (2011-2013) of a lake and glacial complex of the northeast foot of Elbrus (results of space monitoring", Development of regions in the 21 st century. Materials I of the international conference devoted to year of environmental protection in Russia. Vladikavkaz, 2013, Vol. 1, pp. 190-195, 2013.

[8] M.D. Dokukin, "Modern dynamics (2011-2013) of a lake and glacial complex of the northeast foot of Elbrus (results of space monitoring", Development of regions in the 21 st century. Materials I of the international conference devoted to year of environmental protection in Russia. Vladikavkaz, 2013, Vol. 1, pp. 190-195, 2013.

[9] Catalog of glaciers of the USSR, Vol. 8, North Caucasus. Ch.5. Basins of the rivers of Mulka, Baksan. Moscow: Gidrometeoizdat, 1970.

[10] Catalog of glaciers of the USSR, Vol. 8. North Caucasus. Ch.1-4. River basin of Kuban. Leningrad: Gidrometeoizdat, 1967. 